Sains Malaysiana 51(1)(2022): 121-136

http://doi.org/10.17576/jsm-2022-5101-10

\title{
Pencirian Jujukan Genom Mitokondria Spesies Rafflesia (Rafflesiaceae) di Semenanjung Malaysia
}

(Characterisation of Mitochondrial Genome Sequences of Rafflesia Species (Rafflesiaceae) in Peninsular Malaysia)

Qiong Chin, Mohd-Noor Mat-Isa, Mohd-Faizal AbU-BAKar, Norfarhan Mohd-AssaAd \& KiEW-Lian

$\mathrm{WAN}^{*}$

ABSTRAK

Rafflesia terkenal sebagai tumbuhan yang menghasilkan bunga tunggal yang terbesar di dunia. Namun, ia semakin jarang ditemui dan ialah spesies dalam bahaya. Sistem pengelasan spesies Rafflesia ialah komponen penting dalam usaha pemuliharaan lazimnya bergantung kepada pencirian morfologi bunga. Walau bagaimanapun, pendekatan molekul, termasuk yang berasaskan kepada jujukan genom mitokondria (mtDNA), berupaya menyediakan kaedah pengelasan yang lebih berkesan. Untuk meneroka kemungkinan ini, jujukan mtDNA empat spesies Rafflesia di Semenanjung Malaysia, iaitu R. cantleyi, R. azlanii, R. kerrii dan R. sharifah-hapsahiae telah dihimpun dan dicirikan dalam kajian ini. Bacaan jujukan mtDNA untuk setiap spesies kajian pada mulanya telah ditentukan masing-masing daripada set data genom keseluruhan menggunakan pendekatan pemetaan berbantukan rujukan. Proses penghimpunan secara de novo dan perancahan kemudiannya telah dijalankan ke atas bacaan jujukan yang telah dikenal pasti untuk menghasilkan jujukan $m t D N A$ bagi R. cantleyi (441,992 pb), R. azlanii (472,723 pb), R. kerrii (500,932 pb) dan R. sharifah-hapsahiae $(453,747$ pb). Seterusnya, anotasi mtDNA bagi setiap spesies telah mengenal pasti sekurang-kurangnya 31 gen pengekodan protein, enam gen tRNA dan tiga rRNA. Perbandingan gen mitokondria mendapati bahawa beberapa gen seperti cob, rpl10, mttB dan ccmB mempamerkan orientasi yang berbeza dalam spesies Rafflesia yang tertentu manakala analisis penjajaran jujukan berganda menunjukkan jujukan gen nadl adalah berbeza antara keempat-empat spesies Rafflesia yang dikaji. Analisis filogenetik dengan menggunakan jujukan bagi tujuh gen pengekodan protein yang terpelihara berupaya membezakan spesies Rafflesia yang dikaji. Kesimpulannya, hasil pencirian jujukan mDNA menunjukkan bahawa jujukan gen mitokondria yang khusus berupaya membezakan spesies Rafflesia yang dikaji dan berpotensi untuk digunakan bagi tujuan pengenalpastian serta pengelasan spesies Rafflesia dalam usaha pemuliharaan organisma yang unik ini.

Kata kunci: Genomik perbandingan; kepelbagaian genetik; penanda molekul; Rafflesia

\section{ABSTRACT}

Rafflesia is well-known as a plant that produces the largest single flower in the world. However, it is an increasingly rare and endangered species. The Rafflesia species classification system, which is an important component in conservation efforts usually depends on the morphological characterisation of the flower. However, molecular approaches, including those based on mitochondrial genome (mtDNA) sequences, may provide a more effective classification method. To explore this possibility, mtDNA sequences of four Rafflesia species in Peninsular Malaysia, namely R. cantleyi, R. azlanii, R. kerrii and R. sharifah-hapsahiae were assembled and characterised in this study. mtDNA sequencing reads for each of the four species were initially identified from their respective whole genome data sets using the referenceassisted mapping approach. De novo assembly and scaffolding processes were then carried out on the identified mtDNA sequencing reads to produce mtDNA sequences for R. cantleyi (441,992 bp), R. azlanii (472,723 bp), R. kerrii (500,932 bp) and R. sharifah-hapsahiae (453,747 bp). Subsequently, annotation of mtDNA for each species identified at least 31 protein coding, six tRNA and three rRNA genes. Comparative gene analysis showed that several genes such as cob, rpl10, $\mathrm{mttB}$ and $\mathrm{ccmB}$ display different orientation in certain Rafflesia species while multiple sequence alignment analysis showed that the nad1 gene sequence is different between the four Rafflesia species studied. Phylogenetic analysis using seven conserved protein coding gene sequences were able to differentiate the Rafflesia species studied. In conclusion, 
the results of mtDNA sequence characterisation indicate that specific mitochondrial gene sequences are capable of distinguishing the Rafflesia species studied, and have the potential to be used for identification and classification of Rafflesia species in efforts to conserve this unique organism.

Keywords: Comparative genomics; genetic diversity; molecular marker; Rafflesia

\section{Pengenalan}

Rafflesia $\mathrm{R}$. Br (Rafflesiaceae) atau bunga pakma merupakan sejenis genus tumbuhan endofit yang berbunga besar dengan ukuran diameter mencecah sehingga satu meter (Hidayati \& Walck 2016). Kudup Rafflesia boleh mengambil masa sehingga sembilan bulan untuk berkembang menjadi struktur bunga. Namun begitu, bunganya hanya mekar antara empat hingga tujuh hari sahaja sebelum menunjukkan tandatanda awal kematian seperti kelayuan, perubahan warna kelopak dan hilang kesegahan (Nais 2001). Tumbuhan holoparasit ini juga mempunyai ciri yang unik, iaitu ia tidak mempunyai daun, batang dan akar (Sofiyanti \& Choong 2012; Sofiyanti et al. 2016). Tambahan pula, Rafflesia tidak memiliki keupayaan untuk menjalankan proses fotosintesis dan bergantung kepada perumahnya yang spesifik, iaitu Tetrastigma untuk mendapatkan nutrisi dan mineral (Molina et al. 2014; Wicaksono et al. 2016). Gaya hidup Rafflesia, termasuk biologi reproduktif (kitaran berbunga yang panjang dan jangka hayat bunga yang pendek), kekhususan perumah dan ancaman penyahutanan telah dikenal pasti sebagai punca utama yang mengakibatkan penurunan bilangan populasi Rafflesia (Barkman et al. 2017; Mat-Salleh 2007; Tolod et al. 2020).

Setakat ini, lebih daripada 30 spesies Rafflesia telah dikenal pasti dan tumbuhan ini boleh didapati di negara Asia Tenggara seperti Thailand, Filipina, Indonesia dan Malaysia (Lestari et al. 2020; Pelser et al. 2019). Daripada jumlah ini, tujuh spesies Rafflesia boleh dijumpai di Semenanjung Malaysia, termasuk $R$. cantleyi SolmsLaubach, $R$. azlanii Latiff \& Wong, $R$. kerrii Meijer dan R. sharifah-hapsahiae Adam, Mohamed, Aizat-Juhari \& Wan (Adam et al. 2016, 2013; Mat Yunoh 2020). Pengelasan pelbagai spesies Rafflesia secara konvensional dilakukan dengan merujuk kepada morfologi bunga yang hanya mampu menyediakan maklumat terhadap penentuan spesies Rafflesia dari segi pandangan luar sahaja. Kajian biologi molekul semasa mengenai Rafflesia adalah lebih tertumpu kepada pencirian transkriptom (Amini et al. 2019, 2017; Lee et al. 2016; Ng et al. 2018). Selain itu, kajian mengenai gen mitokondria juga telah dijalankan dalam usaha untuk memahami hubungan evolusi Rafflesia kerana gen mitokondria mengalami kadar mutasi yang lebih rendah berbanding dengan gen nuklear (Barkman et al. 2004). Beberapa kajian lain berkaitan gen mitokondria juga telah dijalankan terhadap genus Rafflesia, seperti kajian pemindahan gen secara mendatar (Davis \& Wurdack 2004), hubungan evolusi dan kepelbagaian (Barkman et al. 2004; Bendiksby et al. 2010; Xi et al. 2013) dan kemungkinan kehilangan genom kloroplas (cpDNA) (Molina et al. 2014). Sehubungan itu, kajian yang tertumpu kepada pencirian dan perbandingan jujukan genom mitokondria (mtDNA) spesies Rafflesia perlu dijalankan memandangkan ia berupaya menyumbang kepada pengelasan spesies secara lebih berkesan seterusnya meningkatkan kesedaran terhadap pemuliharaan tumbuhan ini.

Dalam kajian ini, bacaan jujukan mtDNA empat spesies Rafflesia yang terdapat di Semenanjung Malaysia iaitu $R$. cantleyi, $R$. azlanii, $R$. kerrii dan $R$. sharifah-hapsahiae telah diperoleh dan dihimpun. Jujukan mtDNA yang dihasilkan telah dianotasi dan dibandingkan untuk mengenal pasti kepelbagaian genetik bagi empat spesies Rafflesia ini. Seterusnya, beberapa gen mitokondria telah digunakan dalam pembinaan semula pohon filogenetik bagi menilai kegunaan jujukan mtDNA dalam pencirian perhubungan antara spesies. Pemahaman yang diperoleh ini boleh dijadikan sebagai asas untuk membangunkan strategi pengenalpastian dan pengelasan spesies Rafflesia pada peringkat molekul.

\section{BAHAN DAN KAEDAH}

\section{PENGHIMPUNAN JUJUKAN MTDNA SPESIES Rafflesia}

Bacaan jujukan mtDNA spesies Rafflesia telah dikenal pasti dan diasingkan dari set data keseluruhan genom melalui pendekatan pemetaan berbantukan rujukan dan seterusnya bacaan jujukan mtDNA tersebut telah diasingkan dan dihimpun serta diperancahkan untuk menghasilkan jujukan mtDNA masing-masing untuk spesies Raflesia berkenaan. Set data keseluruhan genom untuk kajian ini terdiri dari jujukan hujung berpasangan 
Illumina keseluruhan genom spesies Rafflesia, iaitu $R$. cantleyi dan $R$. sharifah-hapsahiae yang telah disampel di Pahang, Malaysia, dan $R$. azlanii serta $R$. kerrii yang telah disampel di Perak, Malaysia. Untuk mengenal pasti bacaan jujukan mtDNA $R$. cantleyi kajian, jujukan mtDNA $R$. cantleyi yang telah dijana oleh $\mathrm{Xi}$ et al. (2013) telah terlebih dahulu dimuat turun dan dihimpun serta diperancahkan dengan menggunakan perisian ABySS (Simpson et al. 2009). Proses pemetaan bacaan keseluruhan genom $R$. cantleyi kajian kepada jujukan mtDNA rujukan $R$. cantleyi terhimpun ini seterusnya telah dilakukan dengan menggunakan perisian Bowtie2 (Langmead \& Salzberg 2012). Bacaan jujukan mtDNA spesies $R$. cantleyi kajian yang telah dipetakan kepada jujukan mtDNA rujukan ini telah diasingkan dan diproses menggunakan perisian SolexaQA++ (Cox et al. 2010) bagi menyingkirkan bacaan yang mempunyai kualiti skor Phred rendah ( $<$ Q20) dan pendek $(<50 \mathrm{pb})$. Seterusnya, proses penghimpunan dengan menggunakan perisian Velvet (Zerbino 2010) telah dijalankan. Ini diikuti dengan proses perancahan dengan menggunakan perisian SSPACE (Boetzer et al. 2010) untuk mendapatkan kerangka jujukan mtDNA $R$. cantleyi kajian yang terhimpun. Hasil yang diperoleh mendapati perhimpunan jujukan mtDNA $R$. cantleyi kajian mempamerkan statistik penghimpunan yang lebih baik daripada perhimpunan jujukan mtDNA $R$. cantleyi (Xi et al. 2013) yang telah dimuat turun. Oleh itu, untuk mengenal pasti bacaan jujukan mtDNA spesies Rafflesia kajian yang lain, jujukan mtDNA $R$. cantleyi kajian yang terjana telah digunakan sebagai jujukan mtDNA rujukan. Proses pemetaan telah dilakukan dengan menggunakan perisian Bowtie2. Bacaan jujukan mtDNA spesies Rafflesia yang telah dipetakan kepada jujukan mtDNA $R$. cantleyi kajian ini telah diasingkan dan seterusnya telah diproses, dihimpun serta diperancahkan dengan keadah yang sama, seperti yang telah dihuraikan.

\section{PENCIRIAN SAIZ SERTA KANDUNGAN GEN DALAM JUJUKAN MTDNA SPESIES Rafflesia}

Saiz mtDNA spesies Rafflesia yang diperoleh telah dianggarkan dengan menggunakan perisian KmerGenie (Chikhi \& Medvedev 2014). Kelimpahan $k$-mer bagi data mtDNA setiap spesies Rafflesia perlu dianggarkan terlebih dahulu untuk mendapatkan nilai $k$-mer genom terbeza (distinct) yang paling tinggi berbanding dengan hasil menggunakan set $k$-mer yang lain. Oleh itu, sempadan di antara puncak yang sepadan dengan kawasan bacaan tunggal dan lembah permulaan yang sepadan dengan ralat jujukan telah masing-masing dikenal pasti dalam analisis penganggaran saiz mtDNA ini bagi setiap spesies Rafflesia. Saiz mtDNA dianggar berdasarkan pengiraan nisbah jumlah nilai $k$-mer genom terbeza yang bermula dari lembah permulaan sepadan dengan ralat jujukan dan dibahagikan dengan nilai bilangan jujukan kedalaman $k$-mer yang memberi nilai puncak bagi $k$-mer genom terbeza. Seterusnya, kandungan gen mtDNA Rafflesia terhimpun telah ditentukan dengan menggunakan pelayan sesawang MITOFY (Alverson et al. 2010). Penyusunan kandungan mtDNA kemudiannya telah dijalankan berdasarkan hasil penentuan panjang dan kedudukan gen mtDNA spesies Rafflesia dengan menggunakan GenomeVx (Conant \& Wofle 2008).

\section{ANALISIS PERBANDINGAN JUJUKAN MTDNA SPESIES Rafflesia}

Analisis perbandingan jujukan spesies Rafflesia masingmasing telah dilaksanakan bagi setiap gen pengekodan protein mitokondria yang terpelihara iaitu atp1, atp6, cob, matR, nad1, nad6 dan rps3 dengan menggunakan perisian ClustalOmega (Sievers \& Higgins 2018). Dalam kajian ini, jujukan gen mitokondria daripada Rhizanthes lowii dan Sapria himalayana (Jadual 1) telah dimuat turun daripada pangkalan data GenBank (Benson et al. 2015). Setelah kesemua tujuh gen mitokondria dibandingkan melalui analisis penjajaran jujukan berganda, pohon filogenetik telah dibina menggunakan gabungan multilokus gen mitokondria terpelihara dengan $R$. lowii dan $S$. himalayana sebagai kumpulan luar (outgroup). Analisis filogenetik telah dijalankan berdasarkan kaedah kebolehjadian maksimum (maximum likelihood) menggunakan model evolusi penggantian nukleotida GTR (General Time Reversible) dengan kadar keheterogenan Gamma melalui perisian RAxML dan nilai butstrap (bootstrap) sebanyak 1000 kali (Stamatakis 2014). RAxML merupakan perisian yang popular dan banyak digunakan untuk menjalankan analisis filogenetik menggunakan kaedah kebolehjadian maksimum bagi data berskala besar. Perisian ini mengintegrasikan model evolusi GTR dengan algoritma pencarian pokok yang pantas tetapi menghasilkan skor kebolehjadian yang baik bagi mengurangkan beban pengkomputeran tanpa menjejaskan ketepatan hasil analisis filogeni (Surveswaran et al. 2018). Akhirnya, pohon filogenetik telah dipamerkan dengan menggunakan FigTree (Rambaut 2009). 
JADUAL 1. Gen mitokondria bagi spesies Rhizanthes lowii dan Sapria himalayana yang dimuat turun daripada pangkalan data GenBank untuk tujuan pengelasan spesies Rafflesia

\begin{tabular}{|c|c|c|c|}
\hline Spesies & Nama gen & Nombor capaian & Rujukan \\
\hline \multirow[t]{7}{*}{ R. lowii } & atpl & EU280947 & Barkman et al. (2007) \\
\hline & atp6 & EU882283 & Barkman et al. (2008) \\
\hline & $c o b$ & FJ670320 & Wurdack \& Davis (2009) \\
\hline & matR & FJ670389 & Wurdack \& Davis (2009) \\
\hline & nadl & EU882338 & Barkman et al. (2008) \\
\hline & nad6 & FJ669546 & Wurdack \& Davis (2009) \\
\hline & rps3 & FJ669643 & Wurdack \& Davis (2009) \\
\hline \multirow[t]{7}{*}{ S. himalayana } & atpl & AY739076 & Nickrent et al. (2004) \\
\hline & atp6 & EU882268 & Barkman et al. (2008) \\
\hline & $c o b$ & EF135619 & Davis et al. (2007) \\
\hline & matR & AY674561 & Davis \& Wurdack (2004) \\
\hline & nadl & AY674768 & Davis \& Wurdack (2004) \\
\hline & nad6 & EF135397 & Davis et al. (2007) \\
\hline & rps3 & EF135484 & Davis et al. (2007) \\
\hline
\end{tabular}

HASIL

\section{PERHIMPUNAN JUJUKAN MTDNA SPESIES Rafflesia}

Penghimpunan de novo jujukan mtDNA spesies Rafflesia telah dijalankan kerana tumbuhan ini masih tidak mempunyai genom rujukan yang lengkap dalam pangkalan data awam. Penghimpunan jujukan mtDNA spesies Rafflesia menggunakan perisian Velvet telah menghasilkan sebanyak 50 kontig dengan jumlah panjang 400,252 pb bagi $R$. cantleyi, 50 kontig dengan jumlah panjang 435,759 pb bagi $R$. azlanii, 46 kontig dengan jumlah panjang 462,839 pb bagi $R$. kerri dan 41 kontig dengan jumlah panjang 432,119 pb bagi $R$. sharifah-hapsahiae (Jadual 2). Seterusnya, proses perancahan telah dilakukan menggunakan perisian SSPACE terhadap kontig yang terhasil. Kaedah ini boleh menaksir susunan, jarak dan orientasi kontig terhimpun dan menghimpunkan bacaan kontig bersela yang bertindih ke dalam perancah. SSPACE telah menghasilkan sebanyak 21 perancah dengan jumlah panjang 441,992 pb bagi $R$. cantleyi, 38 perancah dengan jumlah panjang 472,723 pb bagi $R$. azlanii, 36 perancah dengan jumlah panjang 500,923 pb bagi $R$. kerrii dan 34 perancah dengan jumlah panjang 453,747 pb bagi $R$. sharifah-hapsahiae (Jadual 2). Jumlah bilangan perancah yang dihasilkan melalui proses ini didapati adalah lebih rendah dengan jumlah jujukan yang lebih panjang berbanding dengan bilangan dan jumlah jujukan kontig yang diperoleh.

\section{SAIZ DAN KANDUNGAN GEN MTDNA SPESIES Rafflesia}

Bagi tujuan pengganggaran saiz mtDNA, anggaran nilai $k$-mer terbaik telah dikenal pasti dengan menggunakan perisian KmerGenie. Saiz mtDNA spesies Rafflesia telah dianggarkan berdasarkan nilai kedudukan puncak yang dibandingkan dengan graf taburan Poisson dan ini telah menghasilkan masing-masing sebanyak 445,084 pb, $480,550 \mathrm{pb}, 512,426 \mathrm{pb}$ dan $466,577 \mathrm{pb}$ bagi spesies $R$. cantleyi, R. azlanii, R. kerrii dan R. sharifah-hapsahiae. Anggaran saiz mtDNA ini adalah berdasarkan kepada bentuk histogram dengan nilai $k$-mer yang optimum, iaitu masing-masing sebanyak 69, 71, 81 dan 71, yang didapati bersesuaian bagi spesies $R$. cantleyi, $R$. azlanii, $R$. kerrii dan R. sharifah-hapsahiae (Jadual 3). Kebanyakan jurang yang ada dalam jujukan mtDNA Rafflesia telah diisikan oleh KmerGenie (Simpson 2014). Oleh itu, saiz jujukan mtDNA yang masih belum lengkap juga telah dianggarkan melalui perbandingan saiz mtDNA terhimpun dengan saiz mtDNA yang dianggarkan 
dengan menggunakan KmerGenie. Jadual 3 menunjukkan terdapat sebanyak 3,092 pb (0.69\%), 7,827 pb (1.63\%), $11,494 \mathrm{pb}(2.24 \%)$ dan $12,830 \mathrm{pb}(2.75 \%)$ jujukan mtDNA yang dijangka masih belum dilengkapkan bagi spesies $R$. cantleyi, $R$. azlanii, $R$. kerrii dan $R$. sharifah-hapsahiae melalui proses penghimpunan mtDNA secara de novo.

Kandungan gen dalam mtDNA spesies Rafflesia telah dianotasi berdasarkan tiga kategori gen yang utama, iaitu gen pengekodan protein, tRNA, dan rRNA. Pencarian gen telah dilakukan berdasarkan pencarian persamaan homolog jujukan mtDNA dengan pangkalan data bagi 41 gen pengekodan protein, 21 gen tRNA dan tiga gen rRNA menggunakan BLAST oleh MITOFY. Hasil analisis ini menunjukkan kehadiran sekurang-kurangnya 40 daripada 65 gen mitokondria di dalam mtDNA setiap spesies Rafflesia yang dikaji (Jadual 4, Rajah 1). Sembilan gen pengekodan protein tidak dapat dikenal pasti di dalam kesemua spesies Rafflesia, iaitu gen $c c m F c$, cox3, rps10, rps11, rps13, rps14, rps19, sdh3 dan sdh4, sementara gen $r p l 2$ didapati hanya hadir dalam jujukan mtDNA $R$. cantleyi dan $R$. sharifah-hapsahiae. Gen tRNA iaitu $\operatorname{trn} C, \operatorname{rrn} E, \operatorname{trn} G, \operatorname{trn} M, \operatorname{trn} P$ dan $\operatorname{trn} S$ telah dikenal pasti dalam keempat-empat jujukan mtDNA Rafflesia. Kesemua jujukan mtDNA Rafflesia didapati mengandungi ketiga-tiga gen rRNA. Secara keseluruhannya, terdapat sekurang-kurangnya 31 daripada 41 gen pengekodan protein, enam daripada 21 tRNA dan kesemua tiga gen rRNA telah dikenal pasti dalam mtDNA spesies Rafflesia yang dikaji.
Hasil analisis anotasi ini turut menunjukkan kedudukan dan organisasi gen dalam jujukan mtDNA Rafflesia. Kandungan gen mitokondria yang dianotasi seperti gen pengekodan protein, tRNA dan rRNA telah dibahagikan berdasarkan fungsi masing-masing untuk tujuan pengelasan jenis gen yang terdapat dalam jujukan mtDNA Rafflesia (Rajah 1). Secara keseluruhannya, organisasi gen dalam keempat-empat spesies Rafflesia ini didapati berbeza antara satu sama lain. Namun demikian, organisasi gen mitokondria $R$. cantleyi adalah lebih serupa dengan $R$. sharifah-hapsahiae manakala organisasi gen mitokondria $R$. azlanii pula adalah lebih menghampiri $R$. kerrii. Misalnya, orientasi gen cob bagi kedua-dua $R$. cantleyi dan $R$. sharifah-hapsahiae adalah dalam orientasi kebelakang manakala bagi $R$. azlanii dan $R$. kerrii pula, ia adalah dalam orientasi kehadapan. Begitu juga dengan gen rpllo yang mempamerkan orientasi kehadapan bagi $R$. cantleyi dan $R$. sharifahhapsahiae, manakala ia tersusun dalam orientasi kebelakang bagi dua spesies Rafflesia yang lain. Di samping itu, gen $m t t B$ dan $c c m B$ juga telah dikesan mempunyai perbezaan orientasi unik, masing-masing di dalam spesies $R$. azlanii dan $R$. sharifah-hapsahiae. Walau bagaimanapun, secara keseluruhannya tahap sinteni bagi keempat-empat mtDNA adalah rendah dan ini memberikan implikasi bahawa penyusunan semula gen mtDNA berlaku sewaktu penspesiesan (Rajah 1).

JADUAL 2. Statistik penghimpunan dan perancahan data mtDNA bagi $R$. cantleyi (Xi et al. 2013) dan spesies Rafflesia kajian, iaitu $R$. cantleyi, $R$. azlanii, $R$. kerrii dan $R$. sharifah-hapsahiae

\begin{tabular}{|c|c|c|c|c|c|}
\hline & $\begin{array}{c}\text { R. cantleyi } \\
\text { (Xi et al. 2013) }\end{array}$ & R. cantleyi & R. azlanii & R. kerrii & R. sharifah-hapsahiae \\
\hline \multicolumn{6}{|l|}{ Selepas penghimpunan } \\
\hline Bilangan kontig & 231 & 50 & 50 & 46 & 41 \\
\hline Jumlah panjang jujukan kontig (pb) & 547,325 & 400,252 & 435,759 & 462,839 & 432,119 \\
\hline Saiz maksimum kontig (pb) & 41,381 & 21,610 & 29,939 & 25,024 & 21,797 \\
\hline Saiz minimum kontig $(\mathrm{pb})$ & 501 & 196 & 150 & 150 & 150 \\
\hline Purata saiz kontig (pb) & 2,369 & 8,005 & 8,715 & 10,061 & 10,539 \\
\hline $\mathrm{N} 50(\mathrm{pb})$ & 11,520 & 14,618 & 15,680 & 18,127 & 17,204 \\
\hline Kandungan GC (\%) & 45.13 & 44.24 & 44.39 & 45.18 & 45.07 \\
\hline \multicolumn{6}{|l|}{ Selepas proses perancahan } \\
\hline Bilangan bacaan perancah & 209 & 21 & 38 & 36 & 34 \\
\hline Jumlah panjang jujukan perancah (pb) & 547,921 & 441,992 & 472,723 & 500,932 & 453,747 \\
\hline Saiz maksimum perancah (pb) & 41,381 & 101,039 & 57,974 & 38,870 & 39,549 \\
\hline Saiz minimum perancah $(\mathrm{pb})$ & 501 & 196 & 150 & 150 & 150 \\
\hline Purata saiz perancah $(\mathrm{pb})$ & 2,622 & 21,047 & 12,440 & 13,914 & 13,345 \\
\hline $\mathrm{N} 50(\mathrm{pb})$ & 15,114 & 33,485 & 18,046 & 21,293 & 18,854 \\
\hline Kandungan GC (\%) & 44.95 & 40.64 & 38.66 & 35.63 & 40.12 \\
\hline
\end{tabular}


JADUAL 3. Statistik penganggaran saiz mtDNA Rafflesia

\begin{tabular}{|c|c|c|c|c|}
\hline & R. cantleyi & R. azlanii & R. kerrii & R. sharifah-hapsahiae \\
\hline Panjang $k$-mer & 69 & 71 & 81 & 71 \\
\hline Jumlah taburan $k$-mer & $141,599,892$ & $15,377,603$ & $5,124,275$ & $3,732,614$ \\
\hline $\begin{array}{l}\text { Saiz mtDNA yang dianggarkan } \\
(\mathrm{pb})\end{array}$ & 445,084 & 480,550 & 512,426 & 466,577 \\
\hline $\begin{array}{l}\text { Jumlah saiz mtDNA terhimpun } \\
(\mathrm{pb})\end{array}$ & 441,992 & 471,723 & 500,932 & 453,747 \\
\hline $\begin{array}{l}\text { Jumlah saiz mtDNA yang tidak } \\
\text { diperoleh }(\mathrm{pb})\end{array}$ & 3,092 & 7,827 & 11,494 & 12,830 \\
\hline $\begin{array}{l}\text { Peratus mtDNA yang belum } \\
\text { dilengkapkan }(\%)\end{array}$ & 0.69 & 1.63 & 2.24 & 2.75 \\
\hline
\end{tabular}

JADUAL 4. Anotasi kandungan gen pengekodan protein, tRNA dan rRNA dalam jujukan mtDNA $R$. cantleyi, $R$. azlanii, $R$. kerrii dan R. sharifah-hapsahiae

\begin{tabular}{|c|c|c|c|c|c|c|c|c|c|}
\hline \multirow{2}{*}{$\begin{array}{l}\text { Padanan } \\
\text { gen }\end{array}$} & & \multicolumn{2}{|c|}{ R. cantleyi } & \multicolumn{2}{|c|}{ R. azlanii } & \multicolumn{2}{|c|}{ R. kerrii } & \multicolumn{2}{|c|}{ R. sharifah-hapsahiae } \\
\hline & & $\begin{array}{l}\text { Saiz } \\
(\mathrm{pb})\end{array}$ & $\begin{array}{c}\text { Jenis } \\
\text { bebenang }\end{array}$ & Saiz (pb) & $\begin{array}{c}\text { Jenis } \\
\text { bebenang }\end{array}$ & $\begin{array}{l}\text { Saiz } \\
(\mathrm{pb})\end{array}$ & $\begin{array}{c}\text { Jenis } \\
\text { bebenang }\end{array}$ & Saiz (pb) & $\begin{array}{c}\text { Jenis } \\
\text { bebenang }\end{array}$ \\
\hline \multicolumn{10}{|c|}{ Gen pengekodan protein } \\
\hline atpl & $\sqrt{ }$ & 1530 & + & 1530 & + & 1530 & + & 1530 & + \\
\hline atp4 & $\sqrt{ }$ & 543 & + & 543 & - & 543 & - & 543 & - \\
\hline atp6 & $\sqrt{ }$ & 801 & + & 801 & - & 801 & + & 801 & - \\
\hline atp 8 & $\sqrt{ }$ & 459 & + & 459 & - & 459 & - & 459 & + \\
\hline atp9 & $\sqrt{ }$ & 102 & + & 102 & + & 102 & + & 102 & + \\
\hline $\operatorname{ccm} B$ & $\sqrt{ }$ & 618 & + & 618 & + & 618 & + & 618 & - \\
\hline $\operatorname{ccm} C$ & $\sqrt{ }$ & 756 & + & 756 & + & 756 & + & 756 & + \\
\hline$c c m F c$ & $\mathrm{x}$ & \multicolumn{2}{|c|}{ tiada } & \multicolumn{2}{|c|}{ tiada } & \multicolumn{2}{|c|}{ tiada } & \multicolumn{2}{|c|}{ tiada } \\
\hline$c c m F n$ & $\sqrt{ }$ & 1761 & - & 1761 & + & 1743 & + & 1761 & - \\
\hline$c o b$ & $\sqrt{ }$ & 1170 & - & 1170 & + & 1170 & + & 1170 & - \\
\hline \multirow[t]{2}{*}{$\operatorname{cox} 1$} & $\sqrt{ }$ & 840 & + & 840 & + & 840 & + & 840 & - \\
\hline & & 726 & + & 726 & + & 723 & + & 726 & - \\
\hline \multirow[t]{2}{*}{$\operatorname{cox} 2$} & $\sqrt{ }$ & 699 & + & 699 & - & 699 & + & 699 & - \\
\hline & & 78 & + & 78 & - & 78 & + & 78 & - \\
\hline $\operatorname{cox} 3$ & $\mathrm{x}$ & \multicolumn{2}{|c|}{ tiada } & \multicolumn{2}{|c|}{ tiada } & \multicolumn{2}{|c|}{ tiada } & \multicolumn{2}{|c|}{ tiada } \\
\hline matR & $\sqrt{ }$ & 1821 & + & 1821 & + & 1821 & + & 1821 & + \\
\hline$m t t B$ & $\sqrt{ }$ & 765 & - & 765 & + & 765 & - & 765 & - \\
\hline \multirow[t]{2}{*}{ nadl } & $\sqrt{ }$ & 309 & - & 309 & - & 309 & - & 309 & - \\
\hline & & 255 & + & 255 & - & 255 & + & 255 & - \\
\hline
\end{tabular}




\begin{tabular}{|c|c|c|c|c|c|c|c|c|c|}
\hline & & & & & & & & & \\
\hline & & 195 & + & 195 & + & 195 & - & 195 & - \\
\hline & & 132 & + & 132 & + & 132 & - & 132 & - \\
\hline & & 57 & + & 57 & + & 57 & + & & \\
\hline nad2 & $\sqrt{ }$ & 645 & - & 645 & - & 645 & + & 645 & + \\
\hline & & 351 & - & 351 & + & 351 & + & 351 & + \\
\hline & & 219 & - & 219 & - & 219 & + & 219 & + \\
\hline & & 162 & - & 162 & - & 162 & + & 162 & + \\
\hline & & 141 & - & 141 & + & 141 & + & 141 & + \\
\hline nad 3 & $\sqrt{ }$ & 357 & - & 357 & - & 357 & + & 357 & + \\
\hline nad4 & $\sqrt{ }$ & 546 & + & 546 & + & 546 & + & 546 & - \\
\hline & & 462 & + & 462 & + & 462 & + & 462 & - \\
\hline & & 459 & + & 459 & + & 459 & + & 459 & - \\
\hline & & 87 & + & 87 & + & 87 & + & 87 & - \\
\hline $\operatorname{nad} 4 L$ & $\sqrt{ }$ & 297 & + & 297 & - & 297 & + & 297 & - \\
\hline nad5 & $\sqrt{ }$ & 1203 & - & 1203 & - & 1203 & + & 1203 & - \\
\hline & & 396 & - & 396 & - & 396 & - & 396 & + \\
\hline & & 237 & - & 237 & - & 237 & + & 237 & - \\
\hline & & 144 & - & 144 & - & 144 & - & 144 & + \\
\hline nad6 & $\sqrt{ }$ & 653 & - & 648 & + & 648 & - & 648 & + \\
\hline $\operatorname{nad} 7$ & $\sqrt{ }$ & 969 & + & 969 & + & 969 & - & 969 & + \\
\hline & & 207 & + & 207 & + & 207 & - & 207 & + \\
\hline & & 126 & + & 126 & + & 126 & + & 126 & + \\
\hline & & 45 & + & 45 & + & 45 & + & 45 & + \\
\hline nad9 & $\sqrt{ }$ & 570 & + & 570 & + & 570 & + & 570 & + \\
\hline rpl2 & $\sqrt{ } / x$ & 93 & + & & & & & 93 & + \\
\hline rpl5 & $\sqrt{ }$ & 501 & + & 507 & - & 507 & - & 501 & + \\
\hline rpl10 & $\sqrt{ }$ & 144 & + & 144 & - & 144 & - & 144 & + \\
\hline & & 75 & + & 75 & - & 75 & - & 75 & + \\
\hline & & 45 & + & 45 & - & 45 & - & 45 & + \\
\hline rpll6 & $\sqrt{ }$ & 408 & + & 408 & - & 408 & - & 408 & + \\
\hline rpsl & $\sqrt{ }$ & 180 & - & 180 & - & 180 & + & 180 & - \\
\hline & & 129 & + & 129 & - & 129 & + & 129 & - \\
\hline & & 120 & + & 123 & - & 120 & + & 123 & - \\
\hline rps 2 & $\sqrt{ }$ & 141 & + & 141 & + & 141 & + & 141 & + \\
\hline & & 102 & - & 102 & + & 102 & - & 102 & + \\
\hline rps 3 & $\sqrt{ }$ & 1560 & + & 1560 & - & 1560 & - & 1560 & + \\
\hline rps 4 & $\sqrt{ }$ & 1008 & - & 1008 & + & 1008 & - & 1008 & + \\
\hline & & 153 & - & 153 & + & 153 & - & 150 & + \\
\hline rps 7 & $\sqrt{ }$ & 336 & - & 336 & - & 336 & + & 666 & - \\
\hline rps 10 & $\mathrm{x}$ & & & & & & & & \\
\hline
\end{tabular}




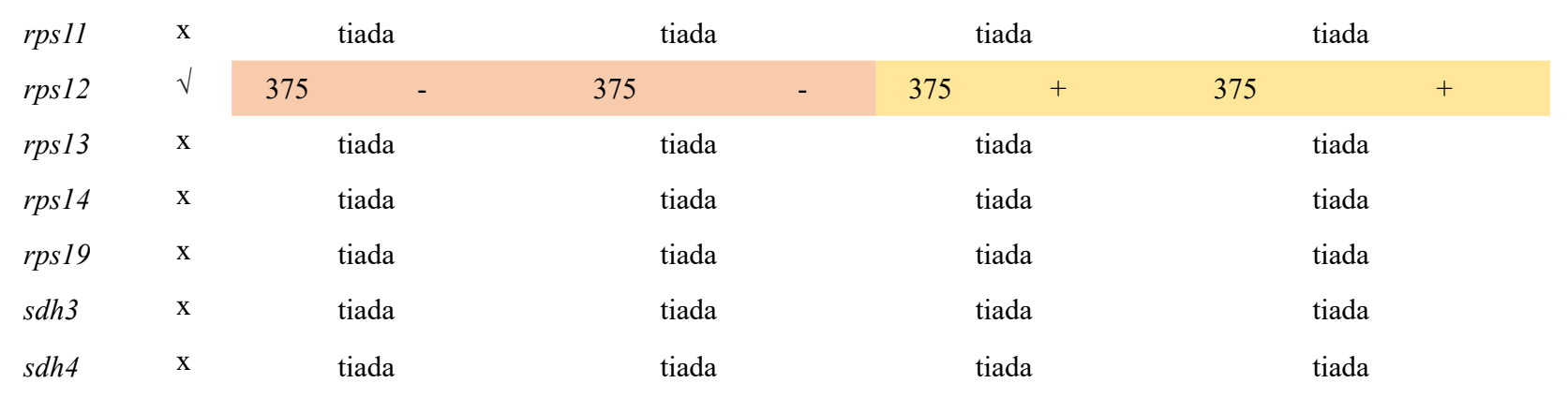

Gen tRNA

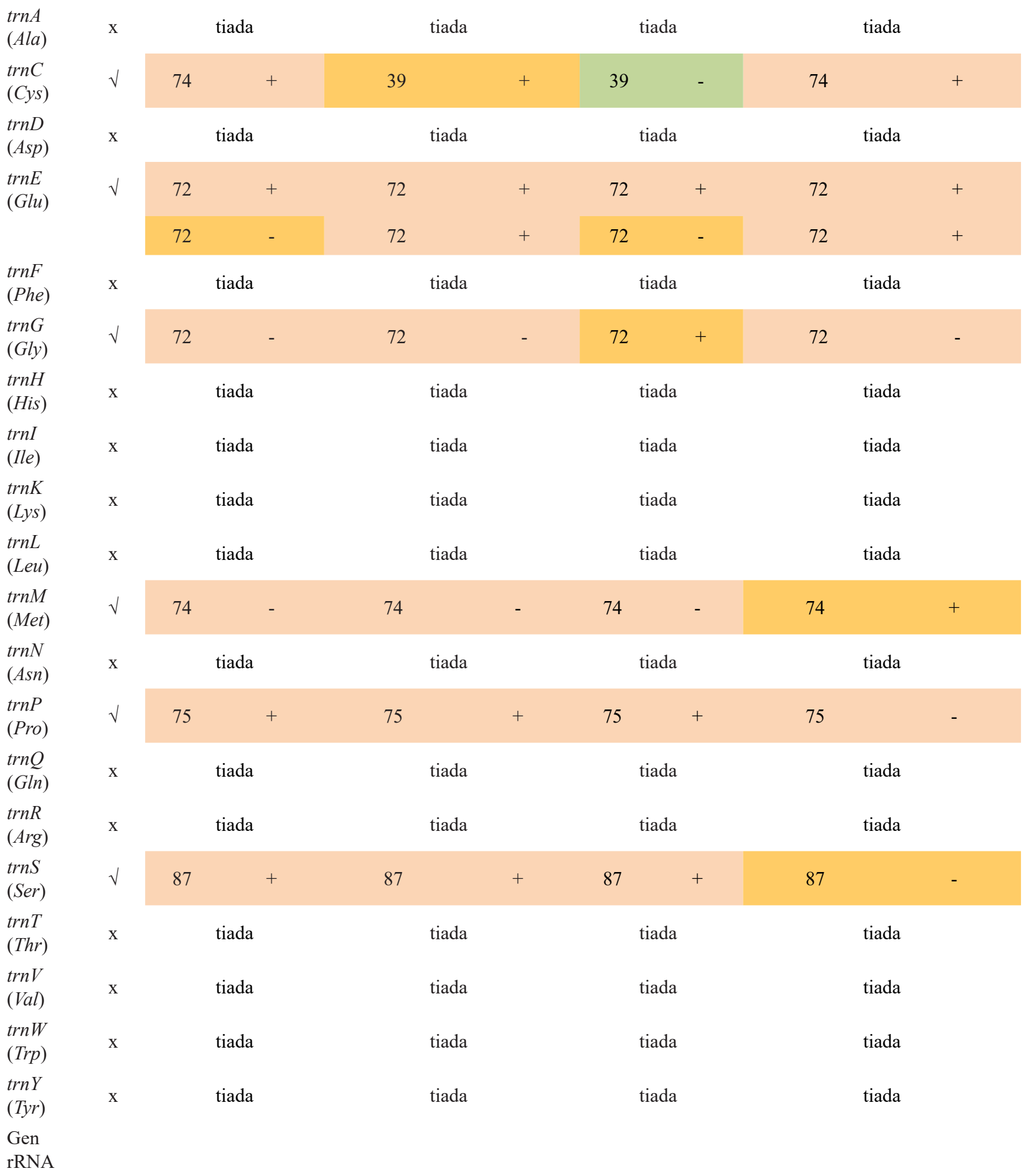




\begin{tabular}{llllllllll}
$r r n 5 s$ & $\sqrt{ }$ & 115 & + & 115 & + & 115 & + & 115 & + \\
$\operatorname{rrnL}$ & $\sqrt{ }$ & 1267 & + & 1267 & + & 1267 & + & 1267 & + \\
$r r n S$ & $\sqrt{ }$ & 1270 & - & 1090 & + & 1082 & + & 1090 & - \\
\hline
\end{tabular}

Baris berbeza bagi gen yang sama menunjukkan pengesanan gen homolog. $V=$ ada padanan dengan pangkalan data gen mitokondria, $x=$ tiada padanan dengan pangkalan data gen mitokondria. Tanda (+) dan (-) menunjukkan arah gen secara kehadapan atau ke belakang, warna yang sama menunjukkan peratus identiti sebanyak $100 \%$ bagi gen yang sama, warna yang berbeza menunjukkan kepelbagaian jujukan bagi gen yang sama

(a)

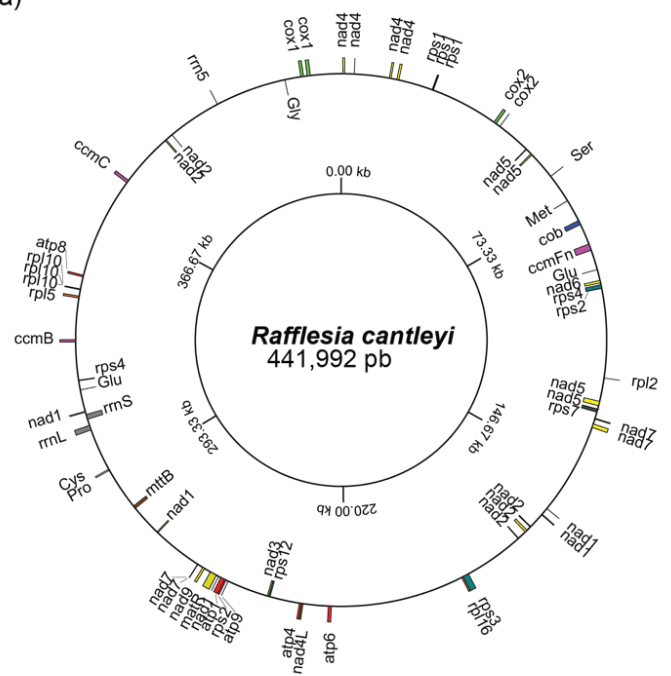

(c)

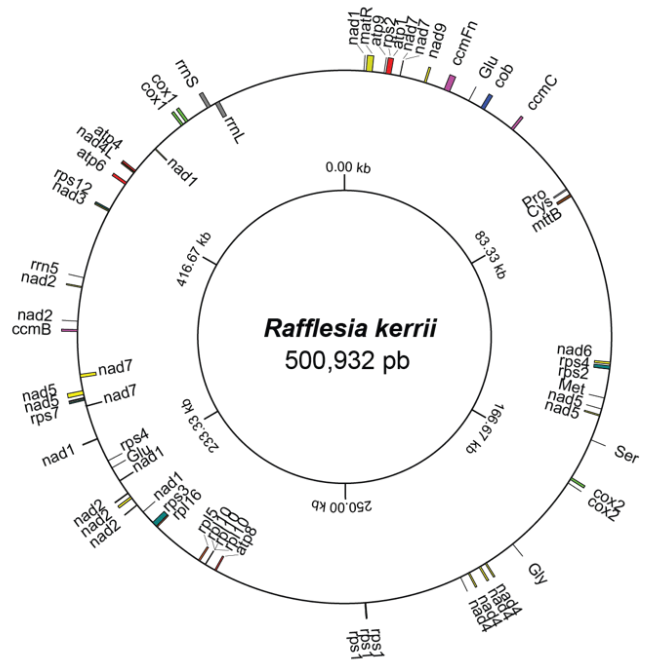

(b)

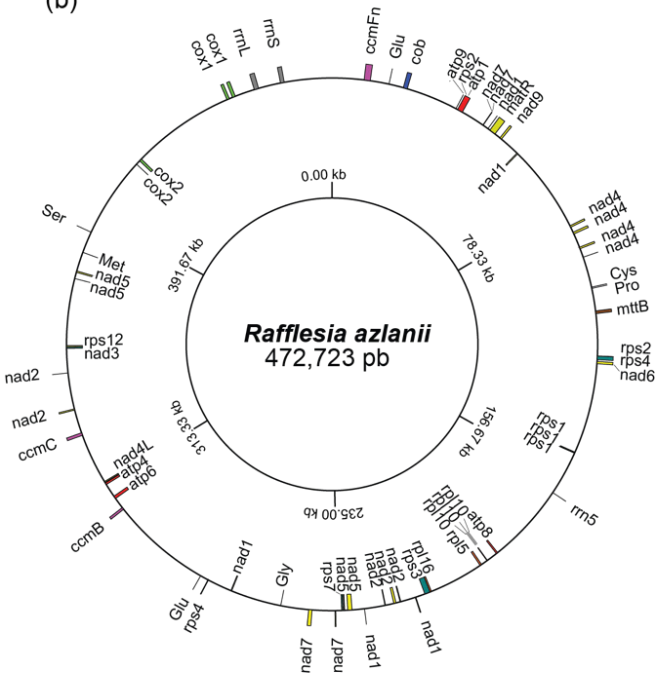

(d)

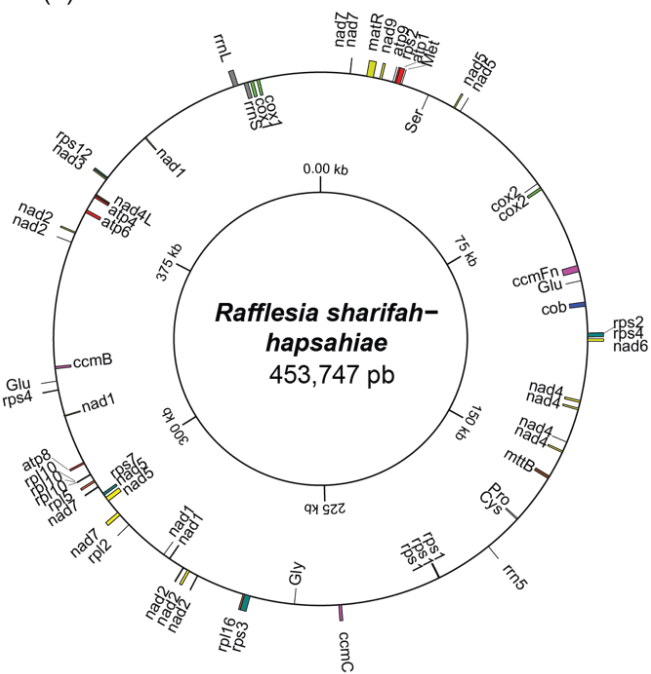

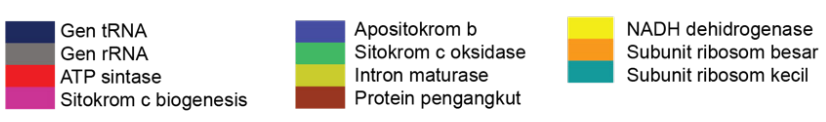

RAJAH 1. Peta bulatan mtDNA spesies Rafflesia. (a) R. cantleyi, (b) R. azlanii, (c) R. kerrii dan (d) $R$. sharifah-hapsahiae. Gen yang berada di luar bulatan merupakan gen yang dikodkan pada bebenang $(+)$ manakala gen yang berada di dalam bulatan merupakan gen yang dikodkan pada bebenang (-). Gen-gen telah diwarnakan masing-masing berdasarkan kumpulan berfungsi 
PERBANDINGAN JUJUKAN DAN PEMBINAAN POHON FILOGENETIK MENGGUNAKAN GEN MITOKONDRIA SPESIES Rafflesia

Analisis penjajaran jujukan berganda telah dilakukan untuk setiap gen mitokondria daripada jujukan mtDNA keempat-empat spesies Rafflesia untuk mengenal pasti persamaan dan perbezaan antara jujukan gen mitokondria tersebut. Hasil analisis penjajaran ini mencadangkan bahawa gen mitokondria seperti nadl yang menunjukkan perbezaan antara keempat-empat spesies Rafflesia yang dikaji, sesuai digunakan dalam pembezaan spesies Rafflesia. Seterusnya, sebanyak tujuh jujukan gen mitokondria yang terpelihara, iaitu atp1, atp6, cob, matR, nad1, nad6 dan rps3, telah digunakan secara gabungan untuk membina pohon filogenetik bagi membezakan spesies Rafflesia yang dikaji. Dua ahli lain dalam keluarga Rafflesiaceae iaitu Rhizanthes dan Sapria yang berdekatan dengan Rafflesia telah digunakan sebagai kumpulan luar dalam analisis ini bagi meningkatkan kebolehan mendiskriminasi spesies Rafflesia kajian. Jujukan gen mitokondria keempat-empat spesies Rafflesia ini masing-masing telah disunting secara manual berikutan penjajaran jujukan berganda gen secara individu bagi memastikan hanya maklumat yang terpelihara digunakan dalam analisis filogenetik.

Hasil analisis jarak berpasangan (pairwise distance) bagi gabungan tujuh jujukan gen mitokondria ini menunjukkan spesies Rafflesia dan spesies kumpulan luar mempunyai peratus identiti yang melebihi $60 \%$. Hasil analisis ini juga menunjukkan bahawa jarak berpasangan antara jujukan $R$. cantleyi dengan $R$. sharifah-hapsahiae mempunyai peratus identiti yang paling tinggi, iaitu sebanyak $87.45 \%$. R. cantleyi juga mempamerkan persamaan identiti sebanyak $78.18 \%$ dengan $R$. kerrii dan $66.07 \%$ dengan $R$. azlanii. Skor matriks identiti ini juga menunjukkan bahawa $R$. azlanii mempunyai persamaan identiti yang lebih hampir dengan $R$. kerrii dengan peratus identiti sebanyak 84.89\% (Jadual 5).

Pohon filogenetik kemudiannya telah dibina dengan menggunakan tujuh jujukan gen mitokondria yang diperoleh daripada analisis penjajaran jujukan berganda. Hasil pohon filogenetik ini menunjukkan bahawa tujuh jujukan gen mitokondria terpelihara yang digunakan dapat membezakan spesies Rafflesia dengan menunjukkan nilai butstrap $100 \%$ antara spesies Rafflesia. Terdapat dua nod cabang dalam pohon filogenetik yang dibina ini, iaitu satu nod mengandungi spesies $R$. cantleyi dan $R$. sharifah-hapsahiae manakala nod yang lagi satu pula mengandungi spesies $R$. azlanii dan R. kerrii (Rajah 2).
Hasil ini menunjukkan perkaitan yang lebih dekat antara $R$. cantleyi dengan $R$. sharifah-hapsahiae manakala $R$. azlanii pula lebih menghampiri kepada $R$. kerrii.

\section{PERBINCANGAN}

Rafflesia mempamerkan morfologi yang unik, terutamanya bunga merah yang bersaiz besar dengan lima lob perigon dan bercorak bintik putih pada permukaannya (Nais 2001). Morfologi bunga Rafflesia biasa digunakan untuk membezakan spesies Rafflesia bagi tujuan pengenalpastian taksonomi. Namun, kaedah pengelasan berdasarkan morfologi ini telah menjadi rumit apabila spesies baharu yang mempunyai ciri morfologi yang serupa ditemui. Pembinaan sistematik tumbuhan berdasarkan kaedah morfologi merupakan cabaran utama kepada ahli botani disebabkan tahap homoplasi yang tinggi antara spesies Rafflesia (Barkman et al. 2008; Bendiksby et al. 2010). Kaedah molekul, yang berasaskan kepada jujukan mtDNA, merupakan alternatif yang berkesan dalam pembezaan spesies. Ini telah ditunjukkan dalam pembinaan hubungan genetik antara spesies Rafflesia dari lokaliti berbeza iaitu Borneo, Indonesia (Sumatera dan Kepulauan Jawa), Semenanjung Malaysia dan Filipina (Bendiksby et al. 2010). Penanda molekul ini juga telah didapati berguna dalam pembinaan semula hubungan filogenetik spesies Rafflesia untuk meramalkan julat leluhur, serta kadar dan corak penyebaran spesies ini (Pelser et al. 2019). Oleh itu, dalam kajian ini, potensi jujukan mtDNA untuk menyediakan kaedah alternatif bagi membezakan spesies Rafflesia pada peringkat molekul telah dikaji dengan lebih lanjut.

Jujukan mtDNA daripada empat spesies Rafflesia di Semenanjung Malaysia, iaitu $R$. cantleyi, $R$. azlanii, $R$. kerrii dan $R$. sharifah-hapsahiae telah dihimpun dan dicirikan dalam kajian ini. Pada mulanya, pendekatan pemetaan kepada jujukan mtDNA rujukan telah digunakan bagi memperoleh bacaan jujukan mtDNA dari set data genom keseluruhan. Untuk $R$. cantleyi kajian, jujukan mtDNA yang telah dijana dari bacaan jujukan $R$. cantleyi yang telah diterbitkan (Xi et al. 2013), telah digunakan sebagai jujukan mtDNA rujukan, manakala bagi spesies Rafflesia kajian yang lain, jujukan mtDNA yang telah dijana dari bacaan jujukan $R$. cantleyi kajian telah digunakan sebagai jujukan mtDNA rujukan. Penghimpunan de novo bacaan jujukan mtDNA yang telah dikenal pasti telah dijalankan menggunakan kaedah pengoptimuman Velvet kerana tumbuhan parasit ini masih tidak mempunyai genom rujukan lengkap dalam pangkalan data awam. Velvet telah dipilih untuk 
JADUAL 5. Peta haba peratus matriks identiti bagi Rhizanthes lowi, Sapria himalayana, dan empat spesies Rafflesia melalui analisis penjajaran jujukan berganda tujuh gen yang terpelihara

\begin{tabular}{lcccccc}
\hline Species & R. lowii & S. himalayana & R. cantleyi & $\begin{array}{c}\text { R. sharifah- } \\
\text { hapsahiae }\end{array}$ & R. azlanii & R. kerrii \\
\hline R. lowii & 100.00 & 82.48 & 71.58 & 67.14 & 68.88 & 70.60 \\
S. himalayana & 82.48 & 100.00 & 76.82 & 72.42 & 70.72 & 72.10 \\
R. cantleyi & 71.58 & 76.82 & 100.00 & 87.45 & 66.07 & 78.18 \\
R. sharifah-hapsahiae & 67.14 & 72.42 & 87.45 & 100.00 & 71.99 & 68.46 \\
R. azlanii & 68.88 & 70.71 & 66.07 & 71.99 & 100.00 & 84.89 \\
R. kerrii & 70.60 & 72.10 & 78.18 & 68.46 & 84.89 & 100.00 \\
\hline
\end{tabular}

Warna menunjukkan kecerunan nilai peratus persamaan: warna oren gelap $=$ persamaan identiti $100 \%$, warna putih $=$ peratus identiti paling rendah $(66.07 \%)$

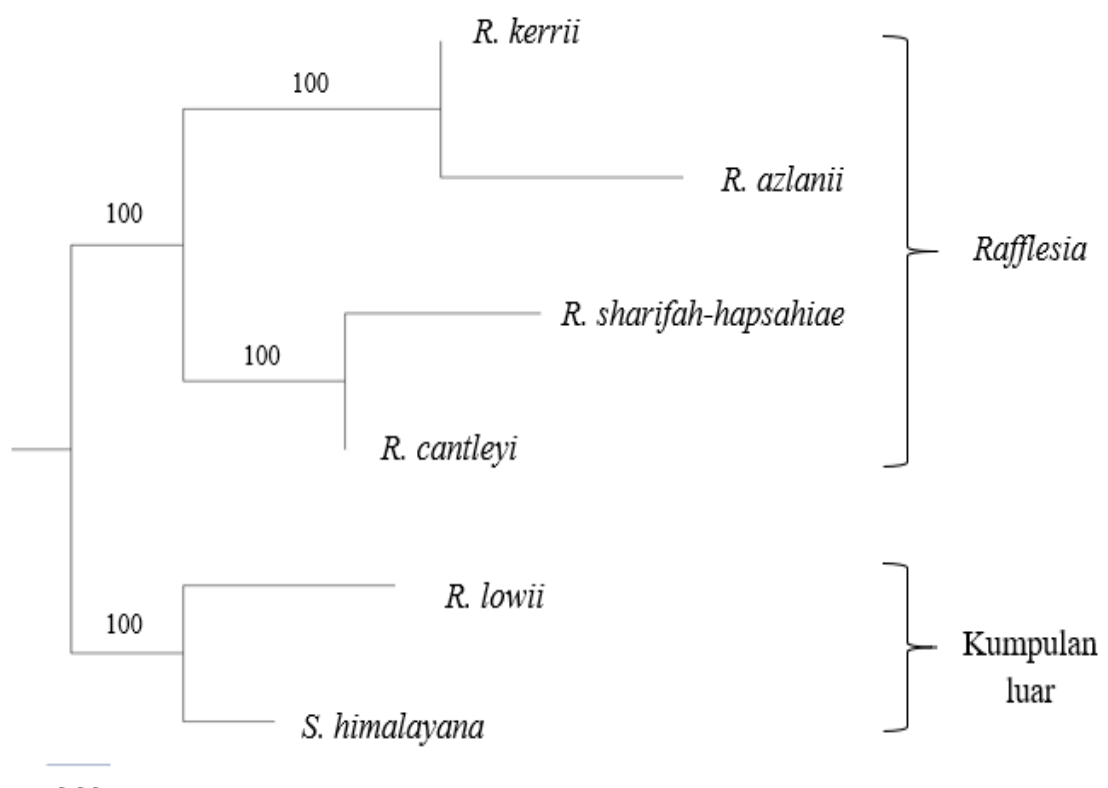

0.06

RAJAH 2. Analisis filogenetik bagi gen mitokondria berbilang untuk spesies Rafflesia, Rhizanthes dan Sapria. Tujuh jujukan gen mitokondria yang terpelihara antara spesies Rafflesia, Rhizanthes dan Sapria, iaitu atp 1, atp6, cob, matR, nad1, nad6 dan rps3 digunakan untuk membina pohon filogenetik melalui kaedah kebolehjadian maksimum menggunakan model GTR dalam program RAxML dengan 1000 kali replikat

menghimpunkan jujukan mtDNA spesies Rafflesia kajian kerana perisian ini dibina dengan kecekapan penggunaan memori yang rendah selain mengambil masa yang lebih pendek untuk menghimpun set data hujung berpasangan (Khan et al. 2018). Panjang cincangan atau $k$-mer yang optimum adalah penting kerana parameter yang telah dioptimumkan boleh mengimbas ruang parameter tersebut secara automatik untuk menghasilkan perhimpunan terbaik dari segi kepekaan dan ketentuan (Zerbino 2010). Seterusnya, proses perancahan telah dilakukan 
menggunakan SSPACE terhadap kontig yang dihasilkan oleh Velvet. Kaedah ini boleh menaksirkan susunan, jarak dan orientasi kontig terhimpun dan menggabungkan bacaan kontig ke dalam perancah. SSPACE dipilih untuk langkah perancahan dalam kajian ini kerana ia berupaya meningkatkan kecekapan pemasangan antara kontig dan bekerja sama dengan Bowtie2 secara berkesan dalam proses pemetaan dan penghimpunan yang perlu dijalankan (Hunt et al. 2014). Bilangan perancah didapati lebih rendah berbanding dengan bilangan kontig selepas proses penghimpunan dan perancahan dijalankan. Ini adalah kerana SSPACE selalu bermula dengan membina bacaan perancah pertama daripada kontig yang paling panjang dan menggabungkan sebanyak mungkin kontig yang mempunyai pertindihan untuk mendapat bacaan perancah (Hunt et al. 2014). Tindakan penyambungan satu kontig dengan kontig lain ini juga menyebabkan bacaan perancah adalah lebih panjang berbanding dengan panjang bacaan kontig yang diperoleh (Boetzer et al. 2010). Proses perancahan yang mengambil kira parameter penting seperti kualiti bacaan adalah amat penting dalam penghasilan perhimpunan jujukan panjang bagi memastikan lebih banyak data bermakna dapat digunakan dalam analisis perbandingan jujukan mtDNA spesies Rafflesia.

Pencirian jujukan mtDNA menunjukkan saiz yang berbeza dalam kalangan mtDNA spesies Rafflesia. Kajian lepas juga menunjukkan saiz yang dinamik dalam kalangan mtDNA tumbuhan disebabkan oleh kadar kehilangan dan penggandaan gen yang tinggi (Chang et al. 2013; Choi et al. 2019; Huang et al. 2020; Palmer et al. 2000). Analisis perbandingan mtDNA spesies angiosperma menunjukkan pola mozek bagi kandungan gen (Sloan et al. 2012). Perubahan yang berlaku pada jujukan gen menyebabkan anotasi berdasarkan kaedah pencarian persamaan homolog kurang berkesan. Selain itu, gen mitokondria mungkin tidak dapat dikesan dalam mtDNA kerana gen mitokondria tersebut telah digantikan oleh gen lain yang berupaya memainkan peranan yang sama atau serupa dan sudah tersedia ada dalam mtDNA. Penggantian gen didapati sering berlaku antara mtDNA, cpDNA dan genom nuklear (nDNA) dalam tumbuhan (Adams et al. 2002a; Mollier et al. 2002; Van de Paer et al. 2018). Begitu juga dengan proses pemindahan gen daripada mtDNA ke nDNA yang didapati berlaku secara berterusan dalam kalangan organisma eukariot, termasuk tumbuhan (Adams et al. 2002b; Adams \& Palmer 2003). Saiz mtDNA didapati semakin berkurang dalam tempoh simbiosis yang panjang kerana berlakunya pemindahan gen dari mtDNA ke nDNA dalam tumbuhan (Yamauchi 2005). Perubahan organisasi mtDNA yang sangat kompleks ini mungkin berkait rapat dengan keupayaan dan keperluan tumbuhan untuk menghadapi perubahan dalam persekitarannya. Oleh itu, organisasi kebanyakan gen tumbuhan yang terlibat dalam aktiviti pertumbuhan dan perkembangan mungkin berubah untuk menyesuaikan perubahan yang dihadapi oleh tumbuhan (Pichersky \& Gerats 2011).

Walaupun gen mitokondria banyak digunakan dalam kajian taksonomi haiwan, gen ini kurang diberi perhatian dalam kajian tumbuhan disebabkan oleh kepelbagaian struktur genom serta kadar mutasi yang rendah antara spesies tumbuhan (Van de Paer et al. 2018). Namun demikian, ketersediaan data jujukan mtDNA telah membuka peluang baharu bagi penerokaan potensi jujukan tersebut dalam kajian evolusi spesies tumbuhan. Gen mitokondria pernah digunakan untuk tujuan perbandingan antara spesies Rafflesia (Bendiksby et al. 2010; Nikolov et al. 2013). Walau bagaimanapun, kajian perbandingan terdahulu yang menggunakan gabungan gen subunit kecil RNA ribosom dan beberapa gen mitokondria tidak berupaya membezakan antara tiga spesies Rafflesia iaitu $R$. cantleyi, R. azlanii dan R. kerrii, yang mana ketiga-tiga spesies ini didapati dikategorikan dalam satu klad yang sama (Bendiksby et al. 2010). Selain itu, hubungan filogenetik antara spesies Rafflesia dengan tumbuhan lain juga telah dikaji, walaupun akhirnya perbezaan interspesies Rafflesia tidak berjaya dilakukan pada peringkat molekul kerana polimorfisme jujukan gen mitokondria yang digunakan adalah rendah (Barkman et al. 2008, 2007; Bendiksby et al. 2010). Hasil tersebut adalah bersesuaian dengan keputusan kajian ini yang menunjukkan bahawa jujukan penanda yang digunakan seperti gen matR mempunyai tahap pemeliharaan yang tinggi. Ini mencadangkan bahawa analisis perbandingan gen yang terdapat dalam mtDNA berupaya untuk mengenal pasti penanda genetik yang lebih berguna bagi pembezaan spesies Rafflesia pada peringkat molekul.

Dalam kajian ini, analisis perbandingan jujukan telah mengenal pasti potensi penggunaan gen mitokondria individu bagi tujuan pembezaan spesies Rafflesia yang dikaji. mtDNA tumbuhan mempunyai saiz yang besar dengan kapasiti pengekodan yang tinggi, kadar mutasi yang rendah dalam gen mitokondria dan kadar penyesuaian semula yang tinggi (Wynn \& Christensen 2019). Kajian yang dijalankan oleh Shedge et al. (2010) mendapati bahawa mtDNA tumbuhan boleh dicirikan dengan pelbagai jenis gabungan seperti kehadiran 
gen berulangan, serta penyelitan dan pengembangan atau pengurangan gen. Hasil kajian ini menunjukkan terdapat perbezaan dalam jujukan dan organisasi gen mitokondria antara spesies Rafflesia yang dikaji. Kewujudan gen individu dalam mtDNA seperti gen nadl yang mempamerkan jujukan yang berbeza antara empat spesies Rafflesia yang dikaji mencadangkan kegunaan gen tersebut dalam pembezaan spesies Rafflesia, manakala gen mitokondria seperti cob, rpl10, $m t t B$ dan $c c m B$ yang mempunyai orientasi yang berbeza dalam spesies Rafflesia tertentu boleh digunakan dalam pembangunan kod bar DNA bagi pengenalpastian spesies Rafflesia tersebut.

Di samping itu, hasil kajian ini juga menunjukkan bahawa penggunaan gen mitokondria gabungan yang terdiri dari atp1, atp6, cob, matR, nad1, nad6 dan rps3 berupaya meleraikan perkaitan filogeni bagi empat spesies Rafflesia yang dikaji. Penggunaan data yang lebih komprehensif daripada mtDNA menghasilkan lebih banyak tapak bermaklumat yang berupaya untuk meleraikan perkaitan hubungan evolusi antara spesies yang tidak dapat dijelaskan sebelum ini (Van de Paer et al. 2018). Kaedah ini menawarkan kemungkinan untuk membangunkan kod bar DNA yang khusus bagi spesies Rafflesia yang dikaji. Pembangunan kod bar DNA untuk tumbuhan adalah amat mencabar kerana pengenalpastian kawasan ataupun jujukan yang berkualiti dan khusus dalam genom diperlukan untuk membolehkan pengecaman spesies dalam variasi intraspesies (Hollingsworth et al. 2011). Walaupun maklumat di peringkat molekul adalah penting dalam pembangunan kod bar DNA tumbuhan, namun pencirian morfologi dan geografi pensampelan juga diperlukan untuk tujuan pengesahan kod bar DNA tersebut (Vere et al. 2015). Oleh itu, selain pengenalpastian kepelbagaian genetik mtDNA, pencirian morfologi dan lokasi pensampelan juga perlu dititikberatkan dalam usaha untuk membangunkan kod bar DNA bagi spesies Rafflesia.

\section{KESIMPULAN}

Dalam kajian ini, perhimpunan jujukan mtDNA bagi setiap spesies Rafflesia telah berjaya dihasilkan. Analisis perhimpunan ini telah berjaya mencirikan kandungan gen dalam jujukan mtDNA spesies Rafflesia tersebut. Di samping itu, kajian ini telah berjaya mengesahkan bahawa jujukan mtDNA empat spesies Rafflesia tempatan yang dikaji mempunyai persamaan dan perbezaan antara satu sama lain melalui analisis penjajaran jujukan berganda. Hasil analisis perbandingan ini telah mengenal pasti jujukan gen mitokondria yang khusus kepada spesies Rafflesia yang tertentu dan berpotensi untuk digunakan bagi membezakan spesies Rafflesia tempatan. Hasil kajian ini juga boleh diperkembangkan untuk diaplikasikan dalam spesies Rafflesia yang lain, termasuklah Rafflesia natif di kawasan geografi yang berbeza. Secara keseluruhannya, kajian ini telah menunjukkan bahawa perbandingan jujukan mtDNA berupaya memberikan pemahaman baharu tentang kepelbagaian genetik spesies Rafflesia serta menyediakan sumber untuk membangunkan strategi pengecaman dan pengelasan spesies yang lebih berkesan bagi organisma yang unik ini.

\section{PENGHARGAAN}

Kajian ini dibiayai melalui Geran Universiti Penyelidikan Universiti Kebangsaan Malaysia (GUP2016-008).

\section{RUJUKAN}

Adam, J.H., Juhari, M.A.A., Mohamed, R., Wahad, N.A.A., Arshad, S., Kamaruzaman, M.P., Mohd Raih, M.F. \& Wan, K.L. 2016. Rafflesia tuanku-halimii n. (Rafflesiaceae), a new species from Peninsular Malaysia. Sains Malaysiana 45(11): 1589-1595.

Adam, J.H., Mohamed, R., Juhari, M.A.A., Nik Ariff, N.N.F. \& Wan, K.L. 2013. Rafflesia sharifah-hapsahiae (Rafflesiaceae), a new species from Peninsular Malaysia. Turkish Journal of Botany 37: 1038-1044.

Adams, K.L. \& Palmer, J.D. 2003. Evolution of mitochondrial gene content: Gene loss and transfer to the nucleus. Molecular Phylogenetics and Evolution 29(3): 380-395.

Adams, K.L., Daley, D.O., Whelan, J. \& Palmer, J.D. 2002a Genes for two mitochondrial ribosomal proteins in flowering plants are derived from their choroplast or cytosolic counterparts. Plant Cell 14(4): 931-943.

Adams, K.L., Qiu, Y.L., Stoutemyer, M. \& Palmer, J.D. 2002b. Punctuated evolution of mitochondrial gene content: High and variable rates of mitochondrial gene loss and transfer to the nucleus during angiosperm evolution. Proceedings of the National Academy of Sciences of the United States of America 99(15): 9905-9912.

Alverson, A.J., Wei, X., Rice, D.W., Stern, D.B., Barry, K. \& Palmer, J.D. 2010. Insights into the evolution of mitochondria genome size from complete sequences of Citrullus lanatus and Cucurbita pepo (cucurbitaceae). Molecular Biology and Evolution 27(6): 1436-1448.

Amini, S., Rosli, K., Abu-Bakar, M.F., Alias, H., Mat-Isa, M.N., Juhari, M.A.A., Haji-Adam, J., Goh, H.H. \& Wan, K.L. 2019. Transcriptome landscape of Rafflesia cantleyi floral buds reveals insights into the roles of transcription factors and phytohormones in flower development. PLOS ONE 14(12): e0226338 
Amini, S., Alias, H., Aizat-Juhari, M.A., Mat-Isa, M.N., Adam, J.H., Goh, H.H. \& Wan, K.L. 2017. RNA-seq data from different developmental stages of Rafflesia cantleyi floral buds. Genomics Data 14: 5-6.

Barkman, T.J., Klooster, M.R., Gaddis, K.D., Franzone, B., Calhoun, S., Manickam, S., Vessabutr, S., Sasirat, S. \& Davis, C.C. 2017. Reading between the vines: Hosts as islands for extreme holoparasitic plants. American Journal of Botany 104(9): 1382-1389.

Barkman, T.J., Bendiksby, M., Lim, S.H., Salleh, K.M., Nais, J., Madulid, D. \& Schumacher, T. 2008. Accelerated rates of floral evolution at the upper size limit for flowers. Current Biology 18(19): 1508-1513.

Barkman, T.J., McNeal, J.R., Lim, S.H., Coat, G., Croom, H.B., Young, N.D. \& dePamphilis, C.W. 2007. Mitochondrial DNA suggests at least 11 origins of parasitism in angiosperms and reveals genomic chimerism in parasitic plants. $B M C$ Evolutionary Biology 7(1): 248-263.

Barkman, T.J., Lim, S.H., Salleh, K.M. \& Nais, J. 2004. Mitochondrial DNA sequences reveal the photosynthetic relatives of Rafflesia, the world's largest flower. Proceedings of the National Academy of Sciences of the United States of America 101(3): 787-792.

Bendiksby, M., Schumacher, T., Gussarova, G., Nais, J., MatSalleh, K., Soyanti, N., Madulid, D., Smith, S.A. \& Barkman, T. 2010. Elucidating the evolutionary history of the southeast asian, holoparasitic, giant-flowered Rafflesiaceae: Pliocene vicariance, morphological convergence and character displacement. Molecular Phylogenetics and Evolution 57(2): 620-633.

Benson, D.A., Clark, K., Karsch-Mizrachi, I., Lipman, D.J., Ostell, J. \& Sayers, E.W. 2015. GenBank. Nucleic Acids Research 43(D1): D30-35.

Boetzer, M., Henkel, C.V., Jansen, H.J., Butler, D. \& Pirovano, W. 2010. Scaffolding pre-assembled contigs using SSPACE. Bioinformatics 27(4): 578-579.

Chang, S., Wang, Y., Lu, J., Gai, J., Li, J., Chu, P., Guan, R. \& Zhao, T. 2013. The mitochondrial genome of soybean reveals complex genome structures and gene evolution at intercellular and phylogenetic levels. PLOS ONE 8(6): e56502.

Chikhi, R. \& Medvedev, P. 2014. Informed and automated $k$-mer size selection for genome assembly. Bioinformatics 30(1): 31-37.

Choi, I.S., Schwarz, E.N., Ruhlman, T.A., Khiyami, M.A., Sabir, J.S.M., Hajarah, N.H., Sabir, M.J., Rabah, S.O. \& Jansen, R.K. 2019. Fluctuations in fabaceae mitochondrial genome size and content are both ancient and recent. BMC Plant Biology 19: 448.

Conant, G.C. \& Wolfe, K.H. 2008. GenomeVx: Simple webbased creation of editable circular chromosome maps. Bioinformatics 24(6): 861-862.

Cox, M.P., Peterson, D.A. \& Biggs, P.J. 2010. SolexaQA: Ata-glance quality assessment of Illumina second-generation sequencing data. BMC Genomics 11: 485.
Davis, C.C. \& Wurdack, K.J. 2004. Host-to-parasite gene transfer in flowering plants: Phylogenetic evidence from Malpighiales. Science 305(5684): 676-678.

Davis, C.C., Latvis, M., Nickrent, D.L., Wurdack, K.J. \& Baum, D.A. 2007. Floral gigantism in Rafflesiaceae. Science 315(5820): 1812

Hidayati, S.N. \& Walck, J.L. 2016. A review of the biology of Rafflesia: What do we know and what's next? Buletin Kebun Raya 19(2): 67-78.

Hollingsworth, P.M., Graham, S.W. \& Little, D.P. 2011. Choosing and using a plant DNA barcode. PLoS ONE 6(5): e19254.

Huang, S., Shi, Y. \& Chen, M. 2020. Mitochondrial genome sequencing and phylogenetic analysis of cynodon dactylon $\mathrm{x}$ cynodon transvaalensis. Turkish Journal of Botany 44(1): $14-24$.

Hunt, M., Newbold, C., Berriman, M. \& Otto, T.D. 2014. A comprehensive evaluation of assembly scaffolding tools. Genome Biology 15(3): R42.

Khan, A.R., Pervez, M.T., Babar, M.E., Naveed, N. \& Shoaib, M. 2018. A comprehensive study of de novo genome assemblers: Current challenges and future prospective. Evolutionary Bioinformatics Online 14: 1-8.

Langmead, B. \& Salzberg, S.L. 2012. Fast gapped-read alignment with Bowtie 2. Nature Methods 9(4): 357-359.

Lee, X.W., Mat-Isa, M.N., Mohd-Elias, N.A., Aizat-Juhari, M.A., Goh, H.H., Dear, P.H., Chow, K.S., Adam, J.H., Mohamed, R., Firdaus-Raih, M. \& Wan, K.L. 2016. Perigone lobe transcriptome analysis provides insights into Rafflesia cantleyi flower development. PLoS ONE 11(12): e 0167958.

Lestari, D., Mahyuni, R. \& Iryadi, R. 2020. Rafflesia pricei Meijer (Rafflesiaceae): A new locality in Borneo. Berita Biologi 19(2): 177-184.

Mat-Salleh, K. 2007. Magnificent Flower of Sabah: Rafflesia. Malaysia: Natural History Publications (Borneo).

Mat Yunoh, S.M. 2020. Notes on a ten-perigoned Rafflesia azlanii from the Royal Belum State Park, Perak, Peninsular Malaysia. Malayan Nature Journal 72(1): 11-17.

Molina, J., Hazzouri, K.M., Nickrent, D., Geisler, M., Meyer, R.S., Pentony, M.M., Flowers, J.M., Pelser, P., Barcelona, J., Inovejas, S.A., Uy, I., Yuan, W., Wilkins, O., Michel, C.I., Locklear, S., Concepcion, G.P. \& Purugganan, M.D. 2014. Possible loss of the chloroplast genome in the parasitic flowering plant Rafflesia lagascae (Rafflesiaceae). Molecular Biology and Evolution 31(4): 793-803.

Mollier, P., Hoffmann, B., Debast, C. \& Small, L. 2002. The gene encoding Arabidopsis thaliana mitochondrial ribosomal protein S13 is a recent duplication of the gene encoding plastid S13. Current Genetics 40(6): 405-409.

Nais, J. 2001. Rafflesia of the World. Malaysia: Natural History Publications (Borneo)

Ng, S.M., Lee, X.W., Mat-Isa, M.N., Aizat-Juhari, M.A., Adam, J.H., Mohamed, R., Wan, K.L. \& Firdaus-Raih, M. 2018. Comparative analysis of nucleus-encoded plastid-targeting proteins in Rafflesia cantleyi against photosynthetic and non- 
photosynthetic representatives reveals orthologous systems with potentially divergent functions. Scientific Reports 8: 17258.

Nickrent, D.L., Blarer, A., Qiu, Y.L., Vidal-Russell, R. \& Anderson, F.E. 2004. Phylogenetic inference in Rafflesiales: The influence of rate heterogeneity and horizontal gene transfer. BMC Evolutionary Biology 4(40): 40-56.

Nikolov, L.A., Endress, P.K., Sugumaran, M., Sasirat, S., Vessabutr, S., Kramer, E.M. \& Davis, C.C. 2013. Developmental origins of the world's largest flower, Rafflesiaceae. Proceedings of the National Academy of Sciences of the United States of America 110(46): 1857818583.

Palmer, J.D., Adams, K.L., Cho, Y.R., Parkinson, C.L., Qiu, Y.L. \& Song, K.M. 2000. Dynamic evolution of plant mitochondrial genomes: Mobile genes and introns and highly variable mutation rates. Proceedings of the National Academy of Sciences of the United States of America 97(13): 6960-6966.

Pelser, P.B., Nickrent, N.L., van Ee, B.W. \& Barcelona, J.F. 2019. A phylogenetics and biogeographic study of Rafflesia (Rafflesiaceae) in the Philippines: Limited dispersal and high island endemism. Molecular Phylogenetics and Evolution 139: 106555

Pichersky, E. \& Gerats, T. 2011. The plant genome: An evolutionary perspective on structure and function. The Plant Journal 66: 1-3.

Rambaut, A. 2009. FigTree v1.2.2 ed. 19. http://tree.bio.ed.ac. uk/software/figtree/. Assessed on 25 Nov 2018.

Shedge, V., Davila, J., Arrieta-Montiel, M.P., Mohammed, S. \& Mackenzie, S.A. 2010. Extensive rearrangement of the Arabidopsis mitochondrial genome elicits cellular conditions for thermotolerance. Plant Physiology 152(4): 1960-1970.

Sievers, F. \& Higgins, D.G. 2018. Clustal omega for making accurate alignments of many protrain sequences. Protein Science 27(1): 135-145.

Simpson, J.T. 2014. Exploring genome characteristics and sequence quality without a reference. Bioinformatics 30(9): 1228-1235.

Simpson, J.T., Wong, K., Jackman, S.D., Schein, J.E., Jones, S.J.M. \& Birol, I. 2009. ABySS: A parallel assembler for short read sequence data. Genome Research 19(6): 1117-1123.

Sloan, D.B., Alverson, A.J., Chuckalovcak, J.P., Wu, M., McCauley, D.E., Palmer, J.D. \& Taylor, D.R. 2012. Rapid evolution of enormous, multichromosomal genomes in flowering plant mitochondria with exceptionally high mutation rates. PLoS Biology 10(1): e1001241.

Sofiyanti, N. \& Choong, C.Y. 2012. Morphology of ovule, seed and pollen grain of Rafflesia $\mathrm{r}$. br (Rafflesiaceae). Bangladesh Journal of Plant Taxonomy 19(2): 109-117.

Sofiyanti, N., Mat-Salleh, K., Mahmud, K., Mazlan, N.Z., Hasein, M.R.A. \& Burslem, D.F.R.P. 2016. Rafflesia parvimaculata (Rafflesiaceae), a new species of Rafflesia from Peninsular Malaysia. Phytotaxa 253(3): 207-213.
Stamatakis, A. 2014. RAxML version 8: A tool for phylogenetic analysis and post-analysis of large phylogenies. Bioinformatics 30(9): 1312-1313.

Surveswaran, S., Gowda, V. \& Sun, M. 2018. Using an integrated approach to identify cryptic species, a divergence patterns and hybrids species in asian ladies' tresses orchids (spiranthes, orchidaceae). Molecular Phylogenetics and Evolution 124 106-121.

Tolod, J.R., Galindon, J.M.M., Atienza, R.R., Duya, M.V., Fernando, E.S. \& Ong, P.S. 2020. Flower and fruit development and life history of Rafflesia consueloae (Rafflesiaceae). Philippine Journal of Science 150(S1): 321-334.

Van de Paer, C., Bouchez, O. \& Besnard, G. 2018. Prospects on the evolutionary mitogenomics of plants: A case study on the olive family (oleaceae). Molecular Ecology Resources 18(3): 407-423.

Vere, N.D., Rich, T.C.G., Trinder, S.A. \& Long, C. 2015. DNA barcoding for plants. Methods in Molecular Biology 1245: 101-118.

Wicaksono, A., Mursidawati, S., Sukamto, L.A. \& Silva, J.A.T.A. 2016. Rafflesia spp.: Propagation and conservation. Planta 244(2): 289-296.

Wurdack, K.J. \& Davis, C.C. 2009. Malpighiales phylogenetics: Gaining ground on one of the most recalcitrant clades in the angiosperm tree of life. American Journal of Botany 96(8): 1551-1570.

Wynn, E.L. \& Christensen, A.C. 2019. Repeats of unusual size in plant mitochondrial genomes: Identification, incidence and evolution. G3: Genes, Genomes, Genetics 9(2): 549-559.

Xi, Z.X., Wang, Y.G., Bradley, R.K., Sugumaran, M., Marx, C.J., Rest, J.S. \& Davis, C.C. 2013. Massive mitochondrial gene transfer in a parasitic flowering plant clade. PLoS Genetics 9(2): e1003265.

Yamauchi, A. 2005. Rate of gene transfer from mitochondria to nucleus: Effects of cytoplasmic inheritance system and intensity of intracellular competition. Genetics 171(3): 1387-1396.

Zerbino, D.R. 2010. Using the Velvet de novo assembler for short-read sequencing technologies. Current Protocols in Bioinformatics 31: 1-12.

Qiong Chin, Mohd-Noor Mat-Isa \& Kiew-Lian Wan*

Jabatan Sains Biologi dan Bioteknologi

Fakulti Sains dan Teknologi

Universiti Kebangsaan Malaysia

43600 UKM Bangi, Selangor Darul Ehsan

Malaysia

Mohd-Noor Mat-Isa \& Mohd-Faizal Abu-Bakar

Malaysia Genome Institute

Jalan Bangi

43000 Kajang, Selangor Darul Ehsan

Malaysia 
Norfarhan Mohd-Assaad

Jabatan Fizik Gunaan

Fakulti Sains dan Teknologi

Universiti Kebangsaan Malaysia

43600 UKM Bangi, Selangor Darul Ehsan

Malaysia
*Pengarang untuk surat-menyurat; email: klwan@ukm.edu.my

Diserahkan: 8 Februari 2021

Diterima: 25 Mei 2021 